Page 1 of 1 1. eDT 629305

\begin{tabular}{|c|c|}
\hline $\begin{array}{l}\text { 2. To } \\
\text { Dist }\end{array}$ & $\begin{array}{l}\text { (Recelving Organization) } \\
\text { ribution }\end{array}$ \\
\hline $\begin{array}{l}\text { 5. Pro } \\
3 \mathrm{~N} 5 \mathrm{C}\end{array}$ & $\begin{array}{l}\text { j./Prog./Dept./Div.: } \\
0\end{array}$ \\
\hline $\begin{array}{l}\text { 8. Ori } \\
\text { For } \\
\text { saf }\end{array}$ & $\begin{array}{l}\text { ginator Remarks: } \\
\text { release of radiation } \\
\text { ety class systems. }\end{array}$ \\
\hline 11. $R$ & aceiver Remarks: \\
\hline 15. & \\
\hline $\begin{array}{l}\text { (A) } \\
\text { Item } \\
\text { No. }\end{array}$ & (B) Document/Drawing No. \\
\hline 1 & $\mathrm{HNF}-63046403$ \\
\hline & की $5-2 \%-00$ \\
\hline & \\
\hline & \\
\hline & \\
\hline & \\
\hline & \\
\hline
\end{tabular}

16.

\begin{tabular}{|c|c|}
\hline Approval Designator (F) & \\
\hline $\begin{array}{l}\text { E, S, O, D OR N/A } \\
\text { (See WHC-CM-3-5, } \\
\text { Sec. 12.7) }\end{array}$ & $\begin{array}{l}\text { 1. Approval } \\
\text { 2. Relesse } \\
\text { 3. Information }\end{array}$ \\
\hline
\end{tabular}

17.
11A. Design Baseline Document? $\bigotimes$ Yes $\square$ No

3. From: (Originating Organization)
WESF Engineering
$\begin{aligned} & \text { 6. Design Authority/Design Agent/Cog. Engr.: } \\ & \text { S. J. Davis }\end{aligned}$

. J. Davis
4. Related EDT No.:
$\mathrm{N} / \mathrm{A}$
7. Purchsse Order No.:
$N / A$
9. Equip./Component No::
$\mathrm{N} / \mathrm{A}$
10. System/Bidg./Facility:
C96A/225B/2C
12. Major Asem. Dwg. No.:
$\mathrm{N} / \mathrm{A}$

13. Permit/Permit Application No.:

$\mathrm{N} / \mathrm{A}$

14. Required Response Date:

$N / A$

\begin{tabular}{|c|c|c|c|}
\hline (F) & $(\mathrm{G})$ & $(\mathrm{H})$ & $(\mathrm{I})$ \\
\hline $\begin{array}{c}\text { Approval } \\
\text { Desig- } \\
\text { nator }\end{array}$ & $\begin{array}{c}\text { Reason } \\
\text { or Trans- } \\
\text { mittal }\end{array}$ & $\begin{array}{c}\text { Origi- } \\
\text { nator } \\
\text { Dispo- } \\
\text { stion }\end{array}$ & $\begin{array}{c}\text { Receiv- } \\
\text { er } \\
\text { Dispo- } \\
\text { sition }\end{array}$ \\
\hline SQ & 1 & 1 & \\
\hline & & & \\
\hline & & & \\
\hline & & & \\
\hline & & & \\
\hline
\end{tabular}

KEY
4. Review

5. Post-Review

6. Dist. (Recelpt Acknow. Required)
Disposition (H) \& (l)

\begin{tabular}{|ll}
\hline \multicolumn{2}{|c}{ Disposition (H) \& (I) } \\
$\begin{array}{ll}\text { 1. Approved } & \text { 4. Reviewed no/comment } \\
\text { 2. Approved w/comment } & \text { 5. Reviewed w/comment } \\
\text { 3. Disapproved w/comment } & \text { 6. Receipt acknowledged }\end{array}$ \\
\hline
\end{tabular}

3. Disapproved w/comment

5. Reviewed w/comment

6. Receipt acknowledged
SIGNATURE/DISTRIBUTION

(See Approval Designator for required signatures)

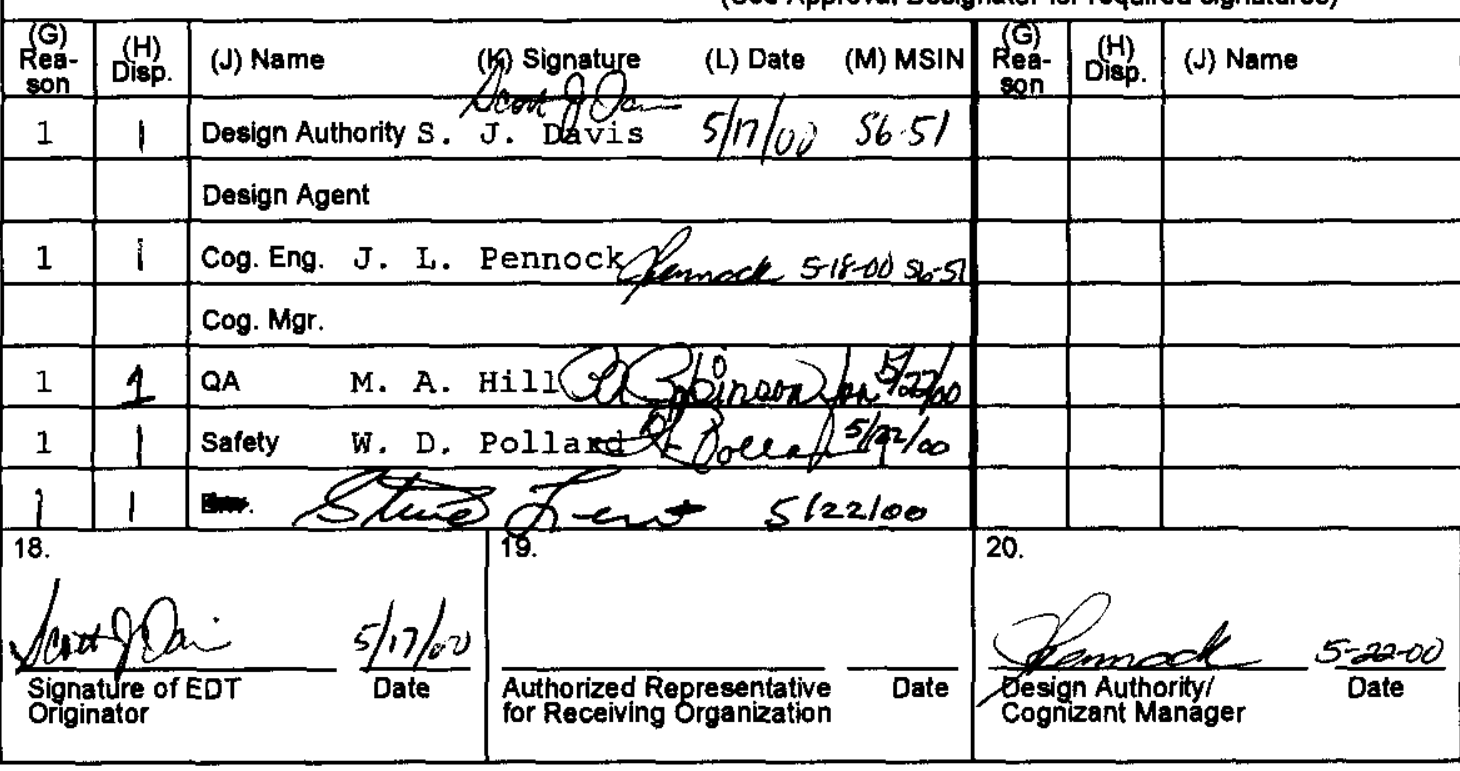

BD-7400-172-2(10/97)
(K) Signature

(L) Date

(M) MSIN
21. DOE APPROVAL (If required) Ctrl No.

$\square$ Approved

$\square$ Approved w/comments

$\square$ Disapproved w/comments 
HNF-6403

Revision 0

CRITICAL

CHARACTERISTICS OF

RADIATION DETECTION

SYSTEM COMPONENTS

TO BE DEDICATED FOR

USE IN SAFETY

CLASS/SAFETY

SIGNIFICANT SYSTEM

Prepared for the U.S. Department of Energy

Assistant Secretary for Environmental Management

Project Hanford Management Contractor for the

U.S. Department of Energy under Contract DE-AC06-96RL13200

Fluor Hanford

P.O. Box 1000

Richland, Washington 
HNF-6403

Revision 0

EDT 629305

\title{
CRITICAL CHARACTERISTICS OF RADIATION DETECTION SYSTEM COMPONENTS TO BE DEDICATED FOR USE IN SAFETY CLASS/SAFETY SIGNIFICANT SYSTEM
}

\author{
S. J. DAVIS \\ FLUOR HANFORD
}

Date Published

May 2000

Prepared for the U.S. Department of Energy

Assistant Secretary for Environmental Management

Project Hanford Management Contractor for the

U.S. Department of Energy under Contract DE-AC06-96RL13200

Fluor Hanford

P.O. Box 1000

Richland, Washington
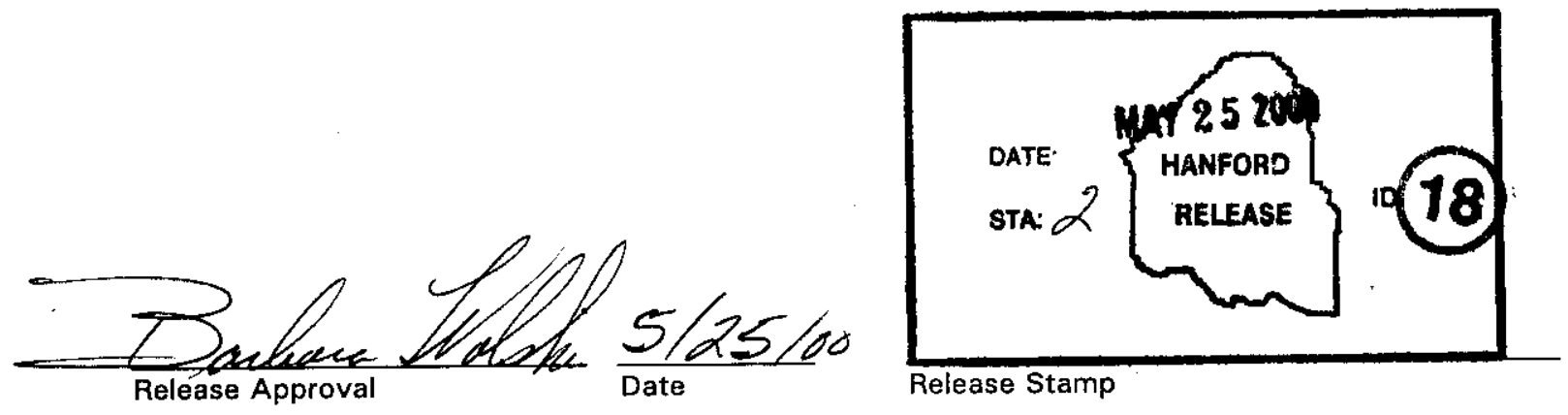
TRADEMARK DISCLAIMER

Reference herein to any specific commercial product, process, or service by trade name, trademark, manufacturer, or otherwise, does not necessarily constitute or imply its endorsement, recommendation, or favoring by the United States Government or any agency thereof or its contractors or subcontractors.

This report has been reproduced from the best available copy.

Printed in the United States of America

Total Pages:

8 


\section{CRITICAL CHARACTERISTICS OF RADIATION DETECTION SYSTEM COMPONENTS TO BE DEDICATED FOR USE IN SAFETY CLASS/SAFETY SIGNIFICANT SYSTEMS}

Prepared by:

Facility Engineering:
S. J. Davis, Engineer, WESF Engineering

S. J. Davis, System Engineer/Test Engineer

M. A. Hill, Quality Assurance Engineer 


\section{Revision Status}

\section{Change}

Number

Rev 0,

Chg [0]
Date

$04 / 20 / 2000$
Change

Document

Page(s)

Description

All
New Supporting Document 


\subsection{PURPOSE AND SCOPE}

This document identifies critical characteristics of components to be dedicated for use in Safety Class (SC) or Safety Significant (SS) Systems, Structures, or Components (SSCs).

This document identifies the requirements for the components of the common radiation area monitor alarm in the WESF pool cell. These are procured as Commercial Grade Items (CGI), with the qualification testing and formal dedication to be performed at the Waste Encapsulation Storage Facility (WESF), in safety class, safety significant systems. System modifications are to be performed in accordance with the instructions provided on ECN 658230. Components for this change are commercially available and interchangeable with the existing alarm configuration

This document focuses on the operational requirements for alarm, declaration of the safety classification, identification of critical characteristics, and interpretation of requirements for procurement. Critical characteristics are identified herein and must be verified, followed by formal dedication, prior to the components being used in safety related applications.

\subsection{REFERENCES}

HNF-SD-WM-SEL-009, Rev. 7, Safety Equipment List

HNF-PRO-268, Rev 5, Control of Purchased Items and Services

HNF-SD-BIO-002, Rev 0, "WESF Basis for Interim Operation"

HNF-SD-IOSR-001, Rev 0, "WESF Interim Operational Safety Requirements"

\subsection{HISTORICAL INFORMATION}

WESF is designed to receive, inspect, decontaminate, and store cesium (Cs) and strontium (Sr) capsules that were produced in past missions at WESF. The capsules were produced in WESF from 1974 to 1985 to reduce the quantity of ${ }^{137} \mathrm{Cs}$ and ${ }^{90} \mathrm{Sr}$ in liquid waste stored in underground tanks. The ${ }^{137} \mathrm{Cs}$, in the form of cesium chloride, and the ${ }^{90} \mathrm{Sr}$, in the form of strontium fluoride, were doubly encapsulated in WESF hot cells and stored under water in WESF pool cells. Some of the cesium capsules were leased to private enterprises for use as radiation sources; these capsules have been returned to WESF. 


\subsection{SAFETY CLASSIFICATIONS}

The Area Radiation Monitor (ARM) system for the Pool Cell Area consists of three detectors, with three remote alarm modules, and a common alarm light and horn. This alarm light and horn provides indication for the facility workers in the Pool Cell Area. Additional indicators are located on panel S-3 and on the WPMCS. The "WESF Safety Equipment List," HNF-SD-WM-SEL-008, Rev 7, identifies the components as Safety Class for the loss of pool cell water accident analysis and safety sionificant for the loss of capsule integrity accident analysis in the WESF BIO.

Procurement must be Safety Class to comply with the requirements established in HNF-PRO-268, Control of Purchased Items and Services, that states, "Services or processes affecting the SSC's functionality shall be classified with the same classification designation as the SSC. All CGI instruments must be qualified and dedicated for Safety Class application.

\subsection{SEISMIC OUALIFICATION FOR THE ALARM MODIFICATION}

The area of concern is the change in weight and the ability of the existing components to support the dead load.

The installation will be less than the current loading as a result of the removal of the un-necessary conduit and fittings. The weight of the alarm/horn assembly is 5.1 pounds. The conduit is anchored in three locations near the light/alarm attachment point. The minimum anchorage in tension for this load is rated at 125 for each $1 / 4$ " anchor, providing a most conservative total tension weight of $375 \mathrm{lbs}$. The total dead load is less than 10 lbs (5.1 pounds plus conduit, fittings and a junction box). The alarm/horn assembly will be supported from the conduit connector and a 4-square box with four $10 \times 32$ screws. Each screw is capable of supporting the weight of $5.1 \mathrm{lbs}$ (weight identified for the horn/alarm assembly). The weight for the alarm/horn assembly is less than the roof loading requirements (20 psf) identified in ROOF-98-028, "Results of the 225B Building Roof Inspection."

Failure of the supports will not create a condition that would damage the capsules and is of no consequence in a seismic event.

\subsection{CRITICAL CHARACTERISTICS}

\subsection{OPERATIONAL REQUIREMENTS:}

Pool cell radiation alarms receive alarm signals and provide visual and audible alarm locally and remotely. (SEL 2.1.3)

\subsection{SAFETY FUNCTION OF THE COMPONENTS:}

1. Alarms (Alarms and Horn) must operate when the alarm set points are exceeded.

2. Alarms must be audible above the background noise. 


\subsection{CONDITIONAL ACCEPTANCE CHARACTERISTICS FOR VERIFICATION BY AVS AT RECEIPT}

1. Label identifying manufacturer and model/part number agrees with the purchase order.

2. No apparent damage has been done to the cable assemblies.

3. QAIP was used to document AVS inspection.

\subsection{FORMAL COMPONENT DEDICATION}

1. Acceptance is to be identified on the QAIP.

2. The Radiation Alarm unit must be tested for acceptance. Initiate an alarm from RE-AR-5, RE-AR-17, and RE-AR-18 verifying the alarm activates and the horn sounds.

3. During the testing performed in step 2, verify that the alarms on Panel S-3 and the WPMCS respond correctly.

When the testing is complete, the System Engineer and the Quality Assurance Engineer will evaluate the data and formally complete the dedication by documenting the acceptance of the items by their signatures in the work package. 